\title{
Discussing the Concepts of Cluster and Industrial District
}

\author{
Francisco Javier Ortega-Colomer ${ }^{*}$, Francesc Xavier Molina-Morales ${ }^{2}$, Ignacio Fernández de Lucio ${ }^{1}$
}

\begin{abstract}
The significance and popularity of the cluster and industrial district concepts claim for a deeper reflection. The analysis of one of the European Commission's (EC) policy documents shows inconsistencies that do not impede the formulation of normative statements. That way we answer the question of why and how cluster ideas have substituted industrial district principles and the consequences derived from that phenomenon.
\end{abstract}

Keywords: Industrial districts; clusters; conceptual analysis; rhetorics; European Commission

Submitted: June $25^{\text {th }} 2015$ / Approved: October $23^{\text {rd }} 2015$

\section{Introduction and Objectives}

Despite the ongoing globalization process, the regional dimension is attracting a lot of interest in terms of the shifts in science, technology and society. For instance, it is well-known that in many countries there has been a process of decentralization of the power authorities (UK, Germany, Austria and Spain are examples). At the same time, regional analysts have been investigating why industries agglomerate and specialize in specific locations, and how firms can profit from this activity -so called, external economies. In fact, regional development can be analysed by identifying the economic, social and institutional dynamics involved, and by redefining the changing role played by different actors and by taking 'the region as a scale of economic organization and political intervention' (MacKinnon et al., 2002, p.293).

Economists and geographers working in these areas have proposed a great range of neologisms "to capture and represent the spatial form and nature of local business concentrations" (Martin and Sunley 2003, p.8). Industrial districts (Becattini 1990), new industrial spaces (Scott 1988), territorial production complexes (Lonsdale 1965), neo- Marshallian nodes (Amin and Thrift 1992), regional innovation milieu (Aydalot 1986), network regions (Martin and Sunley 2003: 8), and learning regions (Florida 1995) are some of the terms that have been suggested (Martin and Sunley 2003 suggested these examples: Scott 1988; Amin and Thrift 1992; Harrison 1992; Harrison et al., 1996; Scott 1998; Markusen 1996; Asheim 2000). However, the most popular of them are industrial district (Becattini 1990) and cluster (Porter 1990), notions that are the focus of this paper.

We should first confirm the extensive use and popularity of these concepts among academics (from disciplines such as geography, economics, management, history and sociology), policy makers (from some European countries, mostly from Italy and Spain), institutions (for instance, the European Commission) and practitioners (consultancy firms, such as Tecnalia). The success of these concepts has resulted in some rather confusing and sometimes chaotic usages, which, at the same time, justify our examination of their conceptual development.
Since 1990, the concepts of industrial district and cluster have been used to refer to the same phenomenon in many regional research writings (Markusen 2003; Lazzeretti 2006). In Spain, both types of policies (industrial districts and clusters) have been employed in various regional programmes. For instance, while cluster policies have been implemented in the Basque Country and Catalonia, the Valencia region has used the industrial district model. In our view, the indiscriminate use of concepts in scientific writing is sometimes due to arbitrary considerations such as the preferences of the journal editors.

Markusen (2003, p.701) described this as terms that 'lack substantive clarity' or as 'fuzzy concepts'. Because these terms arose out of the interaction between the research community and policy-makers they have been coined also as 'transdiscursive terms' (Miettinen 2002, p.133). Others refer to them simply as 'fashion labels' (Martin and Sunley 2003, p.23) because of their temporal nature while the philosopher W. B. Gallie termed them 'essentially contested concepts' for combining general agreement on the abstract notion that they represent with endless disagreement about they might mean in practice (Gallie 1956). However, many authors have made efforts to differentiate these concepts and have warned about the consequences of the confusion or lack of clarity in their use (Markusen 2003; Lastres and Cassiolato 2005; Lazzeretti 2006). Others have strived for a deconstruction of the cluster concept (Martin and Sunley 2003), concluding that in transcending their epistemological boundaries the regional scientist can provoke a misuse of the original concept and ignore the contributions of colleagues.

Our first reaction is that the logic of these concepts (industrial district and cluster) is far from clear and an analysis of their underlying rhetoric is required. To this end, we analysed a European Commission policy document titled The Concept of Cluster and Cluster Policies and their Role for Competitiveness and Innovation: Main statistical results and lessons learned (European Commission 2008). Although, in our opinion, there are some inconsistencies in this document, surprisingly they do not impede the formulation of normative statements.

(1) INGENIO (CSIC-UPV), Universitat Politècnica de València, Valencia, Spain.

(2) Department of Business Administration and Marketing, Universitat Jaume I de Castelló, Spain.

${ }^{*}$ Corresponding author: fraorco@ingenio.upv.es 
For instance, industrial clusters are argued to act as vehicles to foster prosperity at the European level in terms of more employment and higher wages. We perform a critical analysis of this and similar statements.

The paper is structured as follows. The first section discusses the origins and definitions of the concepts. The next section compares their rationales, methodologies and rhetoric. The final section discusses the pitfalls in use of the cluster concept for policy making.

\section{Origins and Definitions of the Concepts of Industrial District and Cluster}

\section{Industrial District}

First, the intellectual detonator for the emergence and development of the industrial district concept was an analysis about the modes of organizing the production process in the early stages of capitalism (Marshall 1890; Marshall 1919). At that time (the end of the $19^{\text {th }}$ century) the hegemonic mode of production was the so-called factory system, where all productive operations were concentrated in the same location (Becattini 2002). Marshall's writings were the source of inspiration for several authors (Brusco 1990; Pyke et al., 1992; Porter 1998; Becattini 2002) who attempted to explain external economies ${ }^{1}$ from an operational point of view. According to Krugman (1991), the agglomeration of firms provides a troika of external economies to the firms located in the same area: economies of specialization, economies of labour pooling and economies of knowledge spillovers, which are on the base of the advantages of these firms. In addition the Marshallian notion of 'industrial atmosphere' captures the flows of intangible resources and knowledge circulating within a district.

This approach re-emerged in the 1970s when some researchers argued that the innovative capacity of some small and medium enterprises in Italy could overcome the decline of the Fordist production model (Becattini 2002). A vast number of case studies on Italy (Becattini 1962; Becattini 1973; Becattini 1979; Gazzero 1973; Fuà 1983; De Angelini (1986); Becattini (1986); De Angelini 1986; Della Vecchia 1987; Ciborra and Longhi 1989; Del Fabbro 1992; among others) became the starting point for a new paradigm. The argument is that while large enterprise suffered from the consequences of both rapid changes in the demand for products and services, and the rise in oil prices, some small enterprises collaborated in order to adapt to this new reality. These firms exchanged knowledge and expertise with other firms in the same sector and firms in their immediate surroundings, thereby enabling several complementarities. The firms involved were mainly engaged in fashion, e.g. shoes and textiles. Becattini (1990, p.38) defines an industrial district as: 'A socio-territorial entity which is characterized by the active presence of both a community of people and a population of firms in one naturally and historically bounded area. In the district, unlike in other environments, such as manufacturing towns, community and firms tend to merge'.

This definition reflects Becattini's attempt to find a unit of analysis beyond the product or technology criteria; such as the Standard
Industrial Classification (SIC) codes. Becattini proposed sense of belonging as a sociological criterion to classify firms belonging to a district (Becattini 1990). However, he needed to find a geographically and cognitively delimited unit of analysis which meant including an entity that was alive and thus shifting continuously. This reality was widely debated among different perspectives such as History, Sociology, Economics (among others) in order to integrate the community of people, population of firms (final product industries plus related and auxiliary industries plus machinery and tools firms) and the institutions or supporting organizations (academic, social institutions or trade associations and others) within the same analytical framework. Becattini was aware of his limitations: he could focus only on a specific natural environment and a specific history of a location where a particular case of possible and likely social evolutions took place simultaneously. He believed that his proposal should include more analytical elements both exogenous (e.g. the evolution of a technological sector) and also the evolution of the set of actors evolved that took account of the stages of birth, growth and decline. He included the sense of belonging to a specific location, territory, culture, tradition and history in the analysis to delimit the industrial district as a stable variable. This enables a better understanding of how some locations have created well-known brand images and why the lines between low-, medium- and high-tech are sometimes blurred.

\section{The Cluster Concept}

The cluster approach traces its roots in a series of case studies in several industrialized countries (Porter 1990). This seminal work provided the basic conceptual framework of clusters and the legitimization for using it in the policy arena, mainly in strictly economic issues. Although the concept of cluster was primarily posed in Porter (1990), it was later defined by him as a geographically proximate group of interconnected companies and associated institutions in a particular field, linked by commonalities and complementarities. The geographic scope of a cluster can be a single city or state or a country or even a network of neighbouring countries' (Porter 1998, p.199).

Porter (1998) extended his original analysis to account for the firm's local environment, including the geographical dimension, to identify, define and scope clusters. His and his group of researchers' main objective was to identify the nature of firm competitiveness which resulted in development of the cluster framework. Porter (1980) proposed the industry attractiveness framework comprised of five competitive forces (threat of substitute products, threat of entry of new competitors, intensity of competition/rivalry, bargaining power of customers, and bargaining power of suppliers). He developed the value chain model to identify sources of competitive advantage at firm-level (Porter 1980) and then proposed the well-known diamond model (Porter 1990) which was followed in Porter (1998) by the cluster framework.

The cluster concept was designed to respond to questions such as why are certain companies located in certain countries able to achieve sustainable competitive advantage. The cluster concept attempts a global

(1) The term 'external economies' was coined by Marshall in a study of the assumed advantages of the factory system as hegemonic model of production: he proposed an alternative model based on a network of small cooperating firms (Marshall, 1919). 
or universal development and applicability, and focuses on searching sources of competitive advantage especially 'knowledge, relationships and motivation' (Porter 1998, p.78). These advantages are difficult for distantly located competitors to integrate in their processes because of the nature of the business environment (Bathelt et al., 2004, Bathelt and Glückler 2014). Only co-located firms are able to benefit and their close location is an entry barrier to 'outsiders'. The cluster concept emerged and has been developed in an era of globalization and is more recent than the concept of industrial district (Lazzeretti 2006). Its widespread use has been encouraged by the marketing efforts of the consultancy firm, Monitor ${ }^{2}$, led by Michael Porter, which has had links to the Institute for Strategy and Competitiveness during its activity. In spite of its increasing popularity in academia and politics (Ketels 2003), the cluster concept has encountered serious criticism that is chaotic, vague and problematic ${ }^{3}$ (Gordon and McCann 2000; Martin and Sunley 2003). The literature review reveals that in trying to differentiate among clusters, more variables were included in the analysis which has resulted in the cluster concept being adapted to enable application to any kind of sector and region.

\section{A Concise Comparison of the Concepts of Industrial District and Cluster}

In this section, we briefly compare the concepts from a critical perspective.

\section{Their Emergence}

From a dynamic perspective, these concepts are continuously evolving. Although Porter and Ketels (2009) defend their common roots, we would argue that their starting points significantly differ. In short, while it is the community of people that matters for Becattini, Porter's point of departure is analysis of the firm's value chain. After that, they converge in giving territory a prominent role.

As already noted, Becattini's original proposal was designed to overcome the limitations of the conventional classifications of firms (e.g. SIC). Sense of belonging was used instead of product or technology similarities as a criterion to group firms. Thus, industrial district is used as a heuristic tool to analyse the economic reality. The district is the unit of analysis, whose frontiers are the most relevant relationships explaining local development. Porter was searching for key issues in the competitive advantage of individual firms. If a firm's activities can be viewed as a number of value chain activities, then its main strategic decisions consist of placing each activity within the most adequate local environment. Thus, the cluster framework is more a theory of the firm, to explain why firm performance varies, that is, why some firms are more successful than others. So, although both concepts use territory or place as the centre of the analysis, the aims, development and final proposals are significantly different.

\section{Their raison d'etre}

If we compare analytical proposals, district and cluster show similarities in terms of justifying the advantages for firm collaboration. First, district externalities can be translated to related and auxiliary activities and factor conditions in the Porterian diamond. Competitive and cooperative duality of district internal relationships is mirrored in part by the local rivalry factor in the Porterian diamond. However, the roles of the institutional settings of district and cluster differ. The institutional setting of an industrial district is described as active in supporting the whole system and offering real services; in the cluster, institutions and government act indirectly or as subsidiary improvements on the diamond. Moreover differences emerge when we consider social aspects. Industrial district refers explicitly to the community of people and the context in which knowledge flows and numerous diverse categories of relationships occur. Porter barely refers to the social aspects of clustering since it is the individual firm that is the focus of the analysis. Social issues are seen to be the result of the economic success of private firms, while the success of economic issues for Becattini is the result of the social cohesion within a community of people.

\section{Their Methodology}

Different methodologies are associated with these concepts, mainly based on case studies. For industrial districts, case studies are used to describe both success stories and cases showing decline. They allow specific and idiosyncratic details to be captured that cannot be observed using other methodological approaches. However, case bias prevents generalization of conclusions. Other strands of research, i.e. the so-called district effect and studies focusing on identifying or mapping districts, attempt to demonstrate district advantages and superiority using comparison analysis. Firms belonging and outside districts are compared in terms of financial performance, innovation capacity, efficiency and other outcomes. These firms are usually in the same industry and the same country. However, the existence of a district effect has been questioned for several reasons, and often as a consequence of the globalization process which is challenging the rather static advantages of district formation.

Research on district identification is related to identifying whether or not a particular area/group can be considered to be an industrial district, i.e. whether the firms in an area are an agglomeration or a conventional district. This analysis uses mainly quantitative methods. It is assumed that not all agglomerations of firms can be identified as industrial districts which require a number of conditions to be fulfilled. These relate in particular to the industrial specialization of the local labour systems. In Porter's works, the cluster effect is rarely applied in a strict way probably because of an implicit assumption by which any group of agglomerated firms can be considered as a cluster, varying only on

(2) http://www.monitorgroup.com.cn/en/idea/leaders/leaders10.asp [accessed January 2009]. In 2012 Monitor group announced its bankruptcy state: http://www.forbes.com/ sites/stevedenning/2012/11/20/what-killed-michael-porters-monitor-group-the-one-force-that-really-matters/

(3) Some authors responded to Martin \& Sunley's article (Benneworth \& Henry 2004). 
the strength of their conditions (Tokunaga et al., 2014). The diamond model acts as a reference for comparison with real cases. The most common type of case study consists of evaluating particular areas at local, regional and/or country level using the diamond as the benchmark.

\section{Their Rhetoric}

The rhetoric accompanying the concepts of district and cluster differs according to the potential audience and actual aims. Becattini uses a rich vocabulary and quite dense texts that are full of metaphors. Aesthetics and the beauty of the writing are important to communicate ideas. Metaphors and other literary devices include the Virtuous circle to refer to the effect of the competition and cooperation in districts, or the caterpillar and the butterfly to explain the process of transformation in the Prato district. Becattini theorizes about familiar realities: Prato is used as an example in much of Becattini's work. It is close to where Becattini lives and works. He can be described as having high levels of very specific knowledge about the reality he studies. Rather than seeing this closeness as a limitation, Becattini considers it as necessary to understand global issues from a local viewpoint.

Porter is much more pragmatic view. His language is aligned to private business consultancy and literary rhetoric is out of place. He discusses what he sees as important (apparent) direct and clear solutions, at expense of loss of some rigour. He uses such terms as competitive, profits and superior, and ranking, optimizing, efficient, economic-based prosperity, etc.

Another kind of fuzziness has been identified by different audiences. The 'industrial district' concept has been criticized by policy-makers because of its fuzziness in terms of its use of metaphors. A nice example is the notion of sense of belonging. Becattini proposed it as a criterion to identify members of a district. The author recognizes the difficulties involved in identifying and using this sociological element. Policy-makers require clear delimitation with regard to the different ambits of the actions of administrative and politically recognized frontiers.

Porter's approach is perhaps clearer, although it has been criticized by regional analysts, mainly geographers, whose work is overlooked in the hypothetical contributions of Porter. The cluster approach does not define the geographical scale with clarity. Also Porter seems opposed to such precision: 'the geographic scope of a cluster can be a single city or state or a country or even a network of neighbouring countries' (Porter 1998, p.199).

The pragmatic and flexible use of these notions has generated confusion among authors trying to build theory and understand how proximity generates advantages for firms (Crawley 2012). According to (Boschma 2005, p.71), proximity implies not only a geographical distance measured, for instance, in kilometres, but also includes 'cognitive, organizational, social, and institutional' dimensions.
Ultimately, both approaches are aimed at different goals. Becattini tries to understand how some Italian areas have reached high levels of developments since the 1970s, elaborating a model to explain how a community of people can be integrated through a population of firms. People are at the centre of the analysis, and economic activities are the mean. Becattini tries to generalize his conclusions to other countries. Porter on the other hand is more interested in the corporate side. $\mathrm{He}$ considers that countries will enjoy higher levels of welfare if its firms are more competitive, achievable through optimal localization in the value chain. Becattini is a renowned academic, while Porter is heavily involved in his consultancy enterprise and the production of strategies for firms.

\section{Use of the Cluster Concept for Policy Making. An example from the European Commission}

For several decades, economists and geographers have strived to integrate into their studies the context and the localization of firms in order to explain differences in performance at different levels (from firm to national or regional ones). In 2008 an EC document (European Commission 2008)4 explicitly addressed the role of clusters in the modern economy. This report apparently answers some of the concerns in the literature about definitions, initiatives and policies. It provides some statistical results and lessons within the cluster framework, to develop this tool to increase prosperity. In the next section, we aim to analyse this document through the light of the above conceptual descriptions.

In fact, this document provides some answers to the questions posed above, although from a slightly different perspective. In our opinion, these answers are problematic because they do not take any other approaches (and consequently other dimensions such as the social) into consideration (e.g. industrial district). Our reading of this report gives support to some previous conceptual revisions. The fact that this policy document deals only with clusters is an indication that the concept of industrial district is considered out-of-date and old-fashioned. For example, the report dedicates only one paragraph to Becattini. This conceptual outshine is part of a broad strategy. This would suggest that the report is economic and narrow in scope.

The aim of the report was 'to present and further analyse the concept of clusters and to inform about main policy approaches in support of clusters' (European Commission 2008, p.7) and complement the broader EU innovation strategy related to the creation of world-class clusters able to compete with clusters in leading countries such as the USA and Japan. Note that the report attempts to provide 'evidence' (European Commission 2008, p.7) of a specific phenomenon: the benefits of localized agglomeration of industries. This debate has been widely discussed in academic circles and their use and application in different contexts and for different purposes is analysed in the literature on cluster typologies and concepts (Porter 1998; Porter 2001; Boari et al., 2003; Tallman et al., 2004; Tripathi 2013). We would

(4) 'The Concept of Clusters and Cluster Policies and their Role for Competitiveness and Innovation. Main Statistical Results and Lessons Learned'. 
contest such a narrow view which sees clusters only as an economic phenomenon whose analysis can be understood, measured and analysed only from an economic dimension. Such a view underestimates the contributions of geographers, sociologists and also economists. Critical views are not reflected (or discussed) in the literature review at all (Gordon and McCann 2000; Martin and Sunley 2003; Cooke 2006). On the other hand some contributions are referred to as success stories. However there is little focus on the benefits that such a heuristic tool provides for understanding the economic success in the Third Italy. Specific and tailored actions to promote and support clusters are required: indiscriminate growth, for instance, in housing and banking clusters has become a social problem as illustrated by some Spanish examples (Torres-López J. 2010; García-Montalvo 2013; Herrero et al., 2013; Sabaté 2014). ${ }^{5}$ If we assume higher economic activity in clusters, we need to differentiate among types of economic activity and clusters that should be supported by policy.

We think that the approach taken in the EC document (2008) cannot be considered to be an 'evidence-based approach' that is directly related to 'prosperity' (European Commission 2008, p.29). The document states that data provide clear evidence in support of clusters. However, in our opinion, the data are far from being clear, well defined, reliable and unlimited (see (European Commission 2008, pp.17-18, 24): 'While many factors other than clustering can have an impact on prosperity, the data provides clear evidence that clusters are significantly related to prosperity (European Commission 2008, pp.28-29).

Due to data limitations a relationship between clusters and prosperity is difficult to prove. The regional agglomeration effects cited are based on employment data only, which requires to be complemented by other indicators e.g. value-added, for them to be meaningful. In addition, the approach adopted is 'deliberately based on the measurement of the revealed effects of clusters' (European Commission 2008, p.18) and assumes that 'the interactions (in and between clusters) are meaningful' (European Commission 2008, p.18) despite differences in type and intensity. Although some of these limitations are acknowledged in the report, they make the promised evidence-based approach impossible. Perhaps the approach should have been described as tentative or exploratory.

The cluster concept in the EC report is linked directly to concepts such as open innovation and the triple helix, which, according to the report, are 'nowadays broadly accepted' (European Commission 2008, p.21). However, also these concepts have been criticized due to their use 'as vehicles to conceptually understand developments that have taken place in particular countries or fields of research' (Tuunainen 2004; Vega-Jurado et al., 2007).

Likewise, it is stated that 'cluster firms interact more frequently with research institutions which are located in proximity than other firms and have an easier access to international networks and capital' (European Commission 2008, p.22). This is refuted in surveys conducted in peripheral and low absorptive capacity regions, such as Valencia (Azagra-Caro, 2007a; Azagra, 2007b; Gutiérrez-Gracia et al., 2008), especially for the science-based clusters, such as biotechnology. The role played by local institutions, including research institutions, has been questioned. The effects of local institutions and public bodies are controversial and have been criticized as being irrelevant and even disruptive to cluster development (see Entrepreneurship and Regional Development, 2006, Special Issue on industrial districts). Finally, in our view this paper conceives that these terms have been taken for granted not based on tested hypotheses or subject to in depth examination. In other words, it is incautious and simplistic to adopt the cluster rhetoric without providing solid data that illustrates the relationship between the agglomerations of industries, the benefits the interaction among the localised actors and the territorial economic prosperity under an evidence-based view.

The European Commission report states the intention to build 'world class clusters' in Europe. Currently only 38\% of all European employees work in enterprises that are part of a cluster' (European Commission 2008, p.25). The method used is (almost) the same than the Porterian one. Although it might allow comparing the two continents, the results have to be taken carefully. For instance, the report states that 'Europe lags on average behind the United States in terms of cluster strength' (European Commission 2008, p.26). However, other reasons such as differences in labour markets and regulatory frameworks, that is, in national and federal laws, could explain these differences between the US and Europe, rather than concentration of employment in clusters. There is also a volume of case study evidence on clusters, although few of these refer to the whole population of Europe (Rodríguez-Pose and Comptour 2010). It is assumed that 'the more specialised a region is the greater the potential for higher wages', but what kind of specialisation offers this result? Would it be better to use relative income available as a complementary indicator?

The question of how the cluster concept is used in the practice of policy making has been mostly overlooked (Ahedo, 2006). Some studies have been done on Spain (Trullén 2009). The present paper tries to separate the different meanings assigned to two regional concepts. (Trullén 2009) argues that the EC for the first time is using a different unit of analysis than sector and administrative unit. According to Trullén, the unit of analysis could guide current economic organization and political intervention aside from the conceptual differences between district and cluster. Trullén sees cluster as a fairly good choice, on the basis that the ambiguity of the concept of cluster has some benefit because it embraces different interpretations, given the diversity of the European countries. Thus, if the European Commission is proposing that the European Union uses cluster to mean a heterogeneous set of concepts (learning region, sector innovator, industrial district, etc.) these concepts could be again put into practice through the cluster lenses, for instance, at other levels of political action: local, regional or sectoral, for instance.

(5) It is well-known that the building cluster in Spain augmented economic activity for several decades. However, the consequences of its indiscriminate growth have become counterproductive in education, employment and other social terms. 
The European Commission 2008 report may help the reader to understand European Commission thinking about convergence towards a hegemonic way of understanding economic development offset by the inclusion of different ways to understand that economic development, e.g. as socio-economic development. We would highlight social as an under-represented dimension in the cluster model, in Porter's seminal work, and in the European Commission document.

It is important to note that industrial district and cluster policies are independent approaches. While industrial district policies were initially implemented in Italy in the 1980s, cluster policies have been used worldwide since the 1990s and have been taking over the idea of industrial district. The European Commission report is illustrative of this in adopting a single approach (based on the cluster perspective) in its aim to promote innovation. This is perhaps why the Commission Staff Working Document SEC (2008) 2637 (European Commission 2008) was delivered as a part of the activities developed by Europe Innova and PRO INNO Europe. Therefore, cluster can be seen as an umbrella concept which has absorbed other approaches.

In Spain, we find both types of policies (industrial districts and clusters) in various regional programmes. While cluster policies have been implemented in the Basque Country and Catalonia, the Valencia region is using the industrial district model. Central government sees the current approach as industrial district-based and Marshall-inspired. Programmes are mainly addressed to 'innovative business groupings' (IBGs) which cooperate on technological development projects.

Before 2004, the industrial district model was not officially recognized beyond the academic level. It can be seen as a bottom-up initiative based mainly on informal connections among the different stakeholders (such as firms, higher education institutions and governments). Since the level of analysis in both approaches tends to be local or regional, rather than national, there might be a conflict of competences and ideologies due to the fact that different political parties govern in different Spanish regions.

According to Trullén (2009, p.731) the district-based policy in Spain represents one of four possible paths:

- Support to large-scale 'industrial research' within large companies (à la Schumpeter), with an ambitious programme financing strategic national consortia for technological research (Consorcios Estratégicos Nacionales de Investigación Tecnológica, CENIT).

- Support to 'technological development' based on 'propulsive companies' (à la Perroux), the idea being to finance industrial development projects driven by large companies, which however had the specific capacity to trigger knock-on effects towards SMEs (the PROFIT programme);
- Support to 'permanent innovation'; this refers to the innovation machine put forward by Baumol (2002), aimed at improving the propensity to innovate of companies more generally regardless of their sector or size, through initiatives that impact on firms' investment decisions on R\&D (for example tax breaks);

- and, last but not least, a support to the innovation capacity of IDs, in particular those of the MID-type according to a Becattinian approach, based on the setting up of innovative business groups and the drafting of strategic plans (the General Office of Small and Medium-sized Companies' IBG Programme), and the financing of technological development projects (the CITD6 agency's financial support programme for IBG7s).

In terms of policy, measurement and evaluation tools we need to highlight that 'A full assessment of their (clusters) impact is not possible at this stage, taking into account the lack of comparable data and the methodological difficulties to measure multiple and long-term effects of horizontal policies' (European Commission 2008, p.8). However, the EC report claims that there is correlation between clusters and prosperity: 'While many factors other than clustering can have an impact on prosperity, the data provides clear evidence that clusters are significantly related to prosperity' (European Commission 2008, p.29), though this has yet to be investigated.

\section{Conclusions}

This paper has provided a review, critique (Section 2) and comparison (Section 3) of the way in which two regional concepts (industrial district and cluster) are understood in the literature. It reflects (Section 4) on how the successful spread of cluster ideas has crowded out the concept of industrial district in a policy document (European Commission 2008).

We can draw some conclusions. First, throughout the paper the extensive use and popularity of territorial concepts was confirmed, particularly the use of those we have focused on. They are popular in all fields, such as academia, and for policy makers, among institutions or even among practitioners. Their use is inconsistent and inaccurate. Their conceptual relevancy and inaccurate application justify a critical examination.

Second, in relation to the unit of analysis, the Porterian cluster serves to build the foundations of the Theory of the Firm, by explaining for instance not only the firm boundaries, but also their heterogeneity and their performance. On the other hand, the industrial district concept aims to provide an alternative way to analyse industries, taking equally the social and the economic issues into account. The territorial dimension is crucial to define the unit of analysis. However, later implementation of the concepts in policy, as shown in the European Commission example, there is a great ambiguity about sites and objects of interventions. Regions or countries arise as administrative ambits toward policy addresses actions.

(6) Centre for the Development of Industrial Technology

(7) Innovative Business Groups, IBGs.

ISSN: 0718-2724. (http://jotmi.org)

Journal of Technology Management \& Innovation (c) Universidad Alberto Hurtado, Facultad de Economía y Negocios. 
Third there is debate about the benefits of defining territorial concepts exhaustively or vaguely to enable wider applicability. Our findings show that one of the reasons why cluster is more popular than industrial district is probably because it is more vague and ambiguous. Policy makers and practitioners prefer simple concepts that capture basic ideas that allow generic and non-restrictive application. For instance, while the term cluster tends to homogenize how regions are addressing economic development, the industrial district approach concentrates on the idiosyncratic situations of particular regions (e.g. the region of Prato). The cluster rationale, following Porter's pragmatic perspective, sometimes omits social aspects that can be crucial to achieving ambitious targets such as prosperity, low unemployment rates, etc. Academics need to be accurate and precise in defining and developing concepts. In our view the examination in this paper helps to identify similarities and differences and reveal the reasons behind some application of these concepts.

\section{Final remarks}

Being so important to deal with the polarization of firms or even the disparities between regions or uneven development in the current European Union, we found problematic the goals and the means of the European Commission document analysed. First, the document is an annex to the European Commission Communication titled Towards world-class clusters in the European Union: Implementing the broadbased innovation strategy, which possibly amplifies the above-mentioned problems. Second, simplifying complex theories developed by geographers in the 20th century to achieve a unique approach (cluster) necessarily overlooks issues that historically were the subject of important discussion from economists, geographers and historians. Many geographers complain about this one-size-fits-all concept.

Also interesting is that the role of universities is as important without a provision of an in-depth analysis of its current role. It is assumed that university has to contribute to this line of thought but some of their members (the academics) are taking part of the debate or simply are unheard.

The authors of the two concepts examined are important. Giacomo Becattini comes from the Emilia Romagna region which has a Communist tradition. Porter is American and probably has a more neo-liberal ideology. Although it would be difficult to claim that Capitalism might be overthrown by, for instance, Communism, Becattini (2002) defends what Sir Samuel Brittan called 'Capitalism with a human face'. Is this last claim what cluster followers want to submerge?

\section{References}

Ahedo, M. (2006). Business Systems and Cluster Policies in the Basque Country and Catalonia (1990-2004). European Urban and Regional Studies, 13(1), 25-39. http://dx.doi.org/10.1177/0969776406059227

Amin, A. \& Thrift, N., (1992). Neo-Marshallian Nodes in Global Networks. International Journal of Urban and Regional Research, 16(4), 571-587. http://dx.doi.org/10.1111/j.1468-2427.1992.tb00197.x
Asheim, B.T. (2000). Industrial districts: the contributions of Marshall and beyond. In The Oxford Handbook of Economic Geography. (pp. 413-431). Oxford: Oxford University Press.

Aydalot, P. (1986). Milieux innovateurs en Europe. Paris: GREMI.

Azagra-Caro J. M. (2007a). The regional dimension of university-industry interaction. In Suriñach J, Moreno R, Vayá E (Eds.) Knowledge externalities, innovation clusters and regional development. (pp. 198218) Edward Elgar, Cheltenham/Northampton.

Azagra-Caro J. M. (2007b). What type of faculty member interacts with what type of firm? Some reasons for the delocalisation of university-industry interaction. Technovation 27(11), 704-715. http:// dx.doi.org/10.1016/j.technovation.2007.05.003

Bathelt, H. Malmberg, A., Maskell, P. (2004). Clusters and knowledge: local buzz, global pipelines and the process of knowledge creation, Progress in Human Geography, 28(1), 31-56. http://dx.doi. org/10.1191/0309132504ph469oa

Bathelt, H. \& Glückler, J. (2014). Institutional Change in Economic Geography, Progress in Human Geography, 38, 340-363. http://dx.doi. org/10.1177/0309132513507823

Becattini, G. (1962). Il concetto di industria e la teoria del valore. Torino, Boringheri.

Becattini, G. (1973). Lo sviluppo economico della Toscana, con particolare riferimento all'industrializzazione leggera, Firenze, IRPET.

Becattini, G. (1979). Dal settore industriale al distretto industriale. Alcune considerazioni sull'unità d'indagine dell'economia industriale. Revista di economia politica e industriale, 1, 7-21.

Becattini, G. (1990). El distrito industrial marshalliano como concepto socioeconómico. In Pyke, F. Los distritos industriales y las pequeñas empresas. Distritos industriales y cooperación interempresarial en Italia, (pp. 61-79) Madrid: Ministerio de Trabajo y Seguridad Social.

Becattini, G. (2002). Del distrito industrial marshalliano a la teoría del distrito industrial contemporánea. Una breve reconstrucción crítica. Investigaciones Regionales, 1, 9-32.

Boari, C., Odorici, V. \& Zamarian, M. (2003). Clusters and rivalry: does localization really matter? Scandinavian Journal of Management, 19(4), pp. 467-489. http://dx.doi.org/10.1016/S0956-5221(03)00035-6

Boschma, R. (2005). Proximity and Innovation: A Critical Assessment. Regional Studies, 39(1), 61-74. http://dx.doi.org/10.1080/0034 340052000320887

Brusco, S. (1990). El concepto de distrito industrial: su génesis. En Los distritos industriales y las pequeñas empresas. Distritos industriales y cooperación interempresarial en Italia, (pp. 25-38) Madrid: Ministerio de Trabajo y Seguridad Social. 
Ciborra, C. \& Longhi, G. (1989). Telematica e territorio nella Terza Italia. Il caso trentino, Milano, FrancoAngeli.

Cooke, P. (2006). Problems and Prospects for Clusters in Theory and Practice. Working Paper

Crawley, A. (2012). An appraisal of the European Cluster Observatory. European Urban and Regional Studies 19(2) pp. 207-211. http:// dx.doi.org/10.1177/0969776411427328

De Angelini, A. (1986). L'industrializzazione diffusa nel Veneto, IRSEV, Milano, FrancoAngeli.

Del Fabbro, P. (1992). Origini e struttura del settore del mobile in Friuli-Venezia Giulia, Oltre il Ponte, 40, pp. 48-75.

Della Vecchia, M. (1987). L'industria bellunese degli anni '80, Oltre il Ponte, 19-20(3-4), pp. 221-242.

European Commission (2008). The Concept of Clusters and Cluster Policies and Their Role for Competitiveness and Innovation: Main Statistical Results. http://dx.doi.org/10.2769/67535

Florida, R. (1995). Towards the learning region. Futures 27(5), 527-536.

Fuà, G. (1983). L'industrializzazione nel Nord-Est e nel Centro, in Fuà G., Zacchia C. (eds), Industrializzazione senza fratture, Il Mulino, (pp. 7-46), Bologna.

Gallie, W. B. (1956). Essentially contested concepts. Proceedings of the Aristotelian Society, vol. 56, pp. 167-198.

García-Montalvo, J. (2013). The Spanish housing market: Is the adjustment over?, SEFO - Spanish Economic and Financial Outlook, 2(5), 15-26.

Gazzero, M. (1973). Un'industria e il suo territorio: i calzaturifici della Riviera del Brenta, Padova, Società cooperativa tipografica.

Gordon, I.R. \& McCann, P. (2000). Industrial Clusters: Complexes, Agglomeration and/or Social Networks? Urban Studies, 37(3), 513532. http://dx.doi.org/10.1080/0042098002096

Gutiérrez-Gracia, A., Fernández de Lucio, I. Todt, O. \& Castro-Martínez, E. (2008). El desarrollo del sector de la Biotecnología: las implicaciones de la alocalización de la Ciencia sobre la Innovación en regiones de baja capacidad de absorción. In Molero-Zayas, J. \& Corona-Treviño, L. (Eds.), Los retos de la innovación en México y España: política, universidad y empresa ante la Sociedad del Conocimiento. (pp. 199-212). Madrid: Akal.

Harrison, B., (1992). Industrial Districts: Old Wine in New Bottles? Regional Studies, 26(5), 469-483. http://dx.doi.org/10.1080/00343409 212331347121

Harrison, B., Kelley, M.R. \& Gant, J. (1996). Innovative Firm Behavior and Local Milieu: Exploring the Intersection of Agglomeration, Firm Effects, and Technological Change. Economic Geography, 72(3), 233-
258. http://dx.doi.org/10.2307/144400

Herrero, M. J., Escavy, J. I. \& Bustillo, M. (2013). The Spanish building crisis and its effect in the gypsum quarry production (1998-2012), Resources Policy, 38(2), 123-129. http:/dx.doi.org/10.1016/j.resourpol.2013.02.005

Ketels, C., (2003). The Development of the cluster concept-present experiences and further developments. En NRW Conference on Clusters, Duisberg, Germany.

Krugman, P.R. (1991). Geography and trade, Cambridge: the MIT Press.

Lastres, H.M.M. \& Cassiolato, J.E. (2005). Systems of innovation, clusters and industrial districts: Analytical and policy implications of convergence and differences in the approaches. III Globelics Conference South Africa. Pretoria.

Lazzeretti, L. (2006). Distritos industriales, "cluster” y otros: un análisis "trespassing” entre la economía industrial y la gestión estratégica. Economía Industrial 359, 59-72.

Lonsdale, R. (1965). The Soviet Concept of the Territorial-Production Complex, Slavic Review, 24(3), 466-478.

Mackinnon, D., Cumbers, A. \& Chapman, K. (2002). Learning, innovation and regional development: a critical appraisal of recent debates. Progress in Human Geography, 26(3), 293-311. http://dx.doi. org/10.1191/0309132502ph371ra

Markusen, A. (1996). Sticky Places in Slippery Space: A Typology of Industrial Districts. Economic Geography, 72(3), 293-313. http://dx. doi.org/10.2307/144402

Markusen, A. (2003). Fuzzy Concepts, Scanty Evidence, Policy Distance: The Case for Rigour and Policy Relevance in Critical Regional Studies. Regional Studies, 37(6-7), 701-717. http://dx.doi. org/10.1080/0034340032000108796

Marshall, A. (1919). Industry and Trade, London: Mcmillan.

Marshall, A. (1890). Principles of economics, London: Mcmillan.

Martin, R. \& Sunley, P. (2003). Deconstructing clusters: chaotic concept or policy panacea? Journal of Economic Geography, 3(1), 5-35. http://dx.doi.org/10.1093/jeg/3.1.5

Miettinen, R. (2002). National innovation system: scientific concept or political rhetoric, Helsinki: Edita.

Porter, M.E. (1998). Clusters and the new economics of competition. Harvard business review, 76(6), 77-90.

Porter, M.E. (1990). Competitive Advantage of Nations, New York: Free Press.

Porter, M.E. (1980). Competitive strategy: techniques for analyzing industries and competitors: with a new introduction, New York: Free Press. 
Porter, M.E. (1998). On competition, Boston: Harvard Business Press.

Porter, M. (2001). Regions and the new economics of competition, in Scott A. J. (ed), Global City-Regions. Trends, theory, Policy, (pp. 137157) Oxford: Oxford University Press.

Porter, M. E. \& Ketels, C. H. M. (2009). Clusters and industrial districts: common roots, different perspectives. In Becattini, G., Bellandi, M. \& De Propis, L. (eds.) A Handbook of Industrial Districts (pp.172-183). Cheltenham: Edward-Edgar.

Pyke, F., Becattini, G. \& Sengenberger, W. (1992). Los distritos industriales y las pequeñas empresas I, Distritos industriales y cooperación interempresarial en Italia. Madrid: Ministerio de Trabajo y Seguridad Social.

Rodríguez-Pose, A. \& Comptour, F. (2010). Do Clusters Generate Greater Innovation and Growth? An Analysis of European Regions. The Professional Geographer, 64(2), 211-231. http://dx.doi.org/10.108 0/00330124.2011.583591

Sabaté, I. (2014). Del país de los propietarios al país de los sobre-endeudados: reciprocidad, solidaridad y proyectos de transformación sistémica en tiempos de crisis, Ars \& Humanitas, 8(1), 168-187. http://dx.doi.org/10.4312/ars.8.1.167-187

Scott, A. J. (1998). Regions and the World Economy: The Coming Shape of Global Production, Competition, and Political Order, Oxford: Oxford University Press.

Scott, A. J. (1988). New industrial spaces: flexible production organization and regional development in North America and Western Europe, London: Pion.
Sum, N. L. (2009). The production of hegemonic policy discourses: 'competitiveness' as a knowledge brand and its (re-)contextualizations, Critical Policy Studies, 3(2), 184-203. http://dx.doi. org/10.1080/19460170903385668

Tallman, S.; Jenkins, M.; Henry, N. Y Pinch, S. (2004). Knowledge clusters and competitive advantage, Academy of Management Review, 29 (2), 258-271. http://dx.doi.org/10.5465/AMR.2004.12736089

Tokunaga, S., Kageyama, M., Akune, Y. \& Nakamura, R. (2014). Empirical Analysis of Agglomeration Economies in the Japanese Assembly-Type Manufacturing Industry for 1985-2000: Using Agglomeration And Coagglomeration Indices, Review of Urban and Regional Development Studies, 26(1), 57-79. http://dx.doi,org/10.1111/ rurd.12019

Torres-López, J. (2010). La Crisis de las Hipotecas Basura. ¿Por Qué Se Cayó Todo y no Se Ha Hundido Nada? Madrid: Ediciones Sequitur. Tripathi, S. (2013). Do Large Agglomerations Lead to Economic Growth? Evidence From Urban India. Review of Urban and Regional Development Studies, 25(3), 176-200. http://dx.doi.org/10.1111/ rurd.12014

Trullén, J., (2009). National industrial policies and the development of industrial districts: reflection on the Spanish case. In Becattini, G., Bellandi, M. \& De Propis, L. (eds.) A Handbook of Industrial Districts (pp. 726-754). Cheltenham: Edward-Edgar.

Tuunainen, J. (2004). Hybrid practices: the dynamics of university research and emergence of a biotechnology company. Helsinki: University of Helsinki.

Vega-Jurado, J., Fernández-de-Lucio, I. \& Huanca-López, R. (2007). La relación universidad-empresa en América Latina: ¿apropiación incorrecta de modelos foráneos? Journal of Technology Management and Innovation, 2(3), 97-109. 